\title{
Proposal Solar Drying With Heat Storage Applied to Medicinal Plants
}

\author{
Valentin Silvera Diaz ${ }^{1,2}$, Eduardo Gonçalves Reimbrecht ${ }^{1}$, Tales Jahn ${ }^{2} \&$ Oswaldo Hideo Ando Junior ${ }^{1}$ \\ ${ }^{1}$ Department of Energies, Federal University of Latin American Integration, Paraná, Brazil \\ ${ }^{2}$ Battery Laboratory, Itaipu Technological Park, Paraná, Brazil \\ Correspondence: Valentin Silvera Diaz, Department of Energies, Federal University of Latin American \\ Integration, Paraná, Brazil. Tel: 55-453-576-7307. E-mail: vsilveradiaz@gmail.com
}

Received: June 11, 2019

doi:10.5539/jas.v11n16p80
Accepted: July 20, $2019 \quad$ Online Published: September 30, 2019

URL: https://doi.org/10.5539/jas.v11n16p80

The research is financed by Federal University of Latin American Integration (UNILA).

\begin{abstract}
In this work, a proposal of an indirect solar dryer with a vacuum solar collector and storage of water-sensitive heater is presented. A mathematical model is presented as the first approximation to evaluate the performance. The test climatic conditions are based on the city of Cascavel (Paraná, Brazil) and the resolution of the model was aided by the EES program. In order to analyze the performance of the system, a model load was created based on the references found in the literature, sample of $80 \mathrm{~kg}$ with initial water content of $75 \%$ w.b and final of $10 \%$ w.b, for drying time of $4 \mathrm{~h}$ and $3 \mathrm{~h}$ with air velocity of $0.7 \mathrm{~m} / \mathrm{s}$ and $1.1 \mathrm{~m} / \mathrm{s}$ respectively. It was possible to simulate the variation of the temperature of the reservoir during the day, as well as the response of the heat exchanger to the variation of temperature of entrance of the fluids and the climatic influence, radiation and ambient temperature in the participation of the solar energy in the total energy consumption of the drying. The simulations suggest good results with solar fraction between 20 and $47 \%$, meanwhile in the literature the values reported are between 10 and $25 \%$.
\end{abstract}

Keywords: sensitive heat storage, thermodynamic model, solar energy

\section{Introduction}

The drying process (DP) is one of the most energy efficient operations in the food industry (Feng et al., 2012). Where the drying process requires a large amount of energy. The drying process in the medicinal plants is an operation of fundamental importance because the dry material presents greater chemical stability, due to the interruption of the metabolic processes that occur even after the material collection (Pimentel, 2008). This allows for easy storage, conservation and commercialization of medicinal and aromatic plants, which are widely used by the pharmaceutical, herbal and cosmetic industries (Lorenzi \& Matos, 2008).

In the DP of medicinal plants, the limits of drying air temperature are determined according to the sensitivity of the active principles of the medicinal plant. In such a way to minimize the losses of essential oil and the active principles during the process (Branquinho et al., 2018).

There is a discussion while at the maximum temperature limit (Castro Melo et al., 2004), an ancient paradigm defended by some authors who recommend that one should not dry medicinal plants with temperature above $40{ }^{\circ} \mathrm{C}$. Although, as presented by Melo et al. (2004), several studies show that temperatures between $50{ }^{\circ} \mathrm{C}$ and $60{ }^{\circ} \mathrm{C}$ are better suited for drying large numbers of medicinal plant leaves, regardless of the drying method employed. Higher temperatures reduce the drying time, so the energy cost per kilogram of water removed decreases (Melo, 2002), influencing the final product price.

By the low temperature, traditionally the drying of medicinal plants has been carried out in the shade or in hand dryers. The use of more efficient dryers can be considered as one of the main alternatives considering phytotherapeutic extracts in commercial scale, considering the volume of production required and the control of the process variables that interfere in the final quality of the product (Goneli et al., 2014). The industrial dryers available in the Brazilian market use as fossil fuel energy sources (wood, biomass and gas) or electric energy (electric resistances), which in the case of small or medium-sized dryers are generally fixed tray type (Mujumdar, 2014). 
The growing market demand for medicinal plants and their derivatives is a profitable alternative to small farmers, given the great demand for this type of product (Vasisht et al., 2016; Tripathi et al., 2017). It is also worth noting that the agribusiness sector consumes about $30 \%$ of the world's energy demand, according to the Energy, Agriculture and Climate Change Report of the United Nations Food and Agriculture Organization (FAO, 2016). In Brazil, the products generated by the agricultural chain contributed $23.9 \%$ of the Gross Domestic Product (GDP) of the country in 2018. About $70 \%$ of these products come from family farming or small rural producers. On the other hand, the electricity distribution infrastructure in rural areas of Brazil is precarious, especially with regard to the stability of the supply, service replenishment when there are falls due to inclement weather and quality of the building electrical installations (Ivanov, 2017).

In this context, aiming to solve a productive and infrastructure problem that exists in Brazil and throughout Latin America. This research presents the proposal and development of a solar dryer that excels in energy efficiency and sustainability, whose operation is based on the use of solar energy as a sustainable alternative that allows maintaining the temperature between $50{ }^{\circ} \mathrm{C}$ and $60{ }^{\circ} \mathrm{C}$ during the whole process of drying and reducing $\mathrm{CO}_{2}$ emissions. Therefore, it is a viable and attractive technology for the drying of medicinal plants for small producers or a rural cooperative adapted to the reality of Latin America.

The present article presents the design and modeling of an indirect solar dryer that is a technical arrangement composed of: sensitive heat storage system having water as the working fluid, using vacuum tube solar collectors and commercial thermal reservoir. In order to validate the proposal, a thermodynamic model is used to analyze the performance of the proposed system.

\section{State of the Art}

In this chapter the state of the art on the development and modeling of solar dryers is presented, in order to support the proposed technological development and present its respective contribution to recent studies.

Prakash and Kumar (2013) have done a comprehensive review on recent trends and reported that forced convection of solar dryers is effective and more controllable than natural circulation. The authors also point out that solar energy can be effectively used for low temperature drying and there is a huge demand for efficient solar dryers incorporated with thermal energy storage medium. To address or limit the intermittent nature of solar energy, as analyzed by Prakash and Kumar (Prakash \& Kumer, 2013), thermal energy storage is proposed as a technical and economically feasible solution for food and agricultural products in general by several researchers (Bennamoun, 2013; Agrawal \& Sarviya, 2016; Bal et al., 2010). Different types of materials such as rock, water, sand and granite, pure paraffin wax and aluminum blend with paraffin wax have been used as thermal storage materials in solar dryers by researchers in the last decades (Agrawal \& Sarviya, 2016). Most sensitive heat storage systems use rocks and water (Bennamoun, 2013; Agrawal \& Sarviya, 2016).

Fudlholi et al. (2015) carried out a technical and economic study of four types of solar dryer systems based on solar water collectors and thermal reservoir for the climatic conditions of Malaysia. The systems compared were: (1) hybrid photovoltaic system with heat pump, (2) system with chemical heat pump, (3) system with dehumidifier and (4) system with heat exchanger. According to the authors, all the evaluated systems presented high performance and stable output temperature suitable for drying process up to $60^{\circ} \mathrm{C}$.

Nems et al. (2018) presented a concept of vertical flow high temperature solar dryer with granite balls in the bed of the dryer acting as thermal storage. Experimental results have shown that granite can prolong the operation of the dryer in two hours.

Considering the medicinal herb market and the desired characteristics, the proposed system differs from other existing technologies by: (i) By the use of individual components (solar collector, reservoir and exchanger) commercially available for confection of the system which the facilitates the customization and replicability of the proposal; (ii) The auxiliary heating system supplies thermal energy directly to the air before entering the drying chamber, allowing greater temperature control and stability; and (iii) Due to the relation between collector and reservoir volume, there is a high solar participation in the final consumption of reducing the use of auxiliary heat source and consequently operating costs.

\section{Design of Solar Dryer}

This chapter presents the design and modeling of the technical arrangement of an indirect solar dryer composed of: sensitive heat storage system having water as working fluid, using solar collectors of vacuum tube and commercial thermal reservoir.

The model proposed in this research will be designed and evaluated for the environmental conditions of the city of Cascavel (Paraná, Brazil) located at coordinates $24^{\circ} 57^{\prime} 21^{\prime \prime} \mathrm{S}$ and $53^{\circ} 27^{\prime} 18^{\prime \prime} \mathrm{W}$. The climatic data used as 
reference for calculations (solar radiation, ambient temperature and relative humidity) were provided by the Paraná Meteorological System (SIMEPAR).

In order to validate the proposal, a thermodynamic model is used to evaluate the system's response to climatic influences. In the performance, two situations will be considered: the first for the month of January, as a favorable operating condition, and the second for the three months with the lowest radiation of the year, June, July and August, as the most unfavorable condition the Brazil.

In order to complement the modeling, a routine was developed in the Engineering Equation Solver (EES) software, which allows to change the following input and influence variables of the system: climate data, collector arrangement, dryer operating parameters flow rate, drying temperature, geometry of the reservoir and the heat exchange.

With the aid of this tool, it is possible to represent and/or estimate the energy consumption in various operating conditions, including simulating load variation of the proposed drying system according to values found in the literature and/or actual data.

\subsection{System Parameters}

\subsubsection{Weather Data}

For the radiation was used the historical of 2002-2013 of the hourly average, the data were processed, obtaining the average of the eleven years for each hour of the year. For the temperature and relative humidity of the air the data period is 2001-2010. In Figure 1 and Figure 2 are presented the monthly hourly average of the radiation and temperature respectively of the months to be used in the calculations.

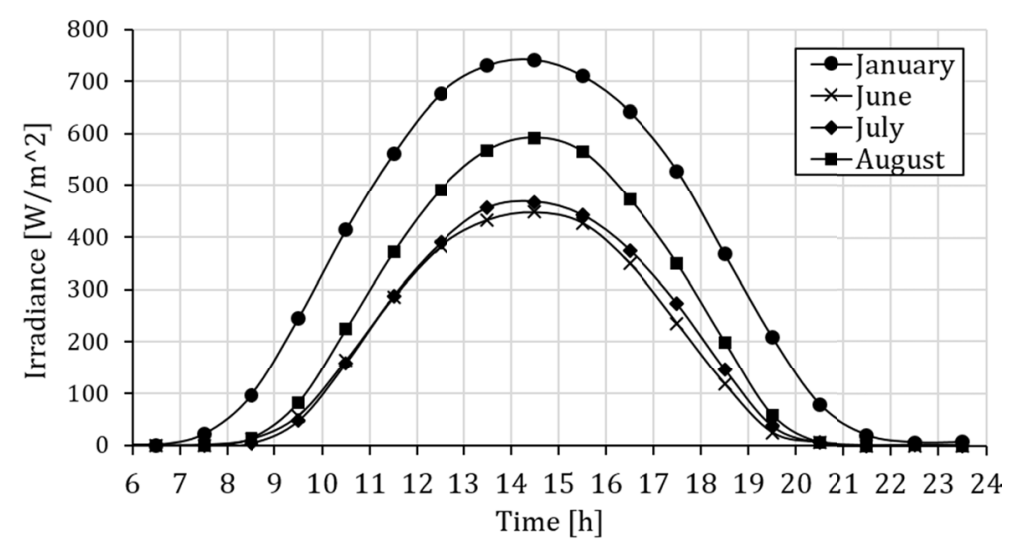

Figure 1. Hourly average of the radiation in the horizontal plane

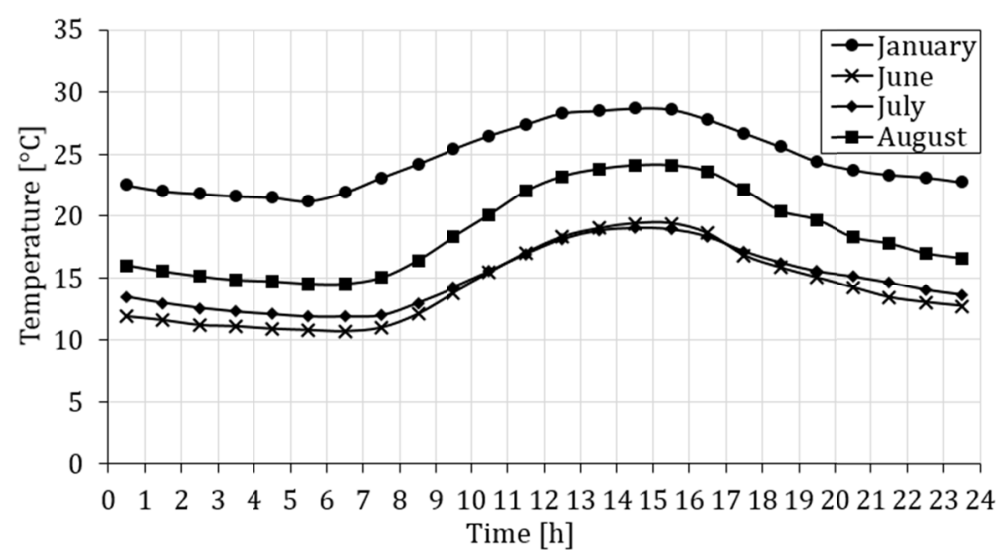

Figure 2. Hourly average ambient temperature

It was observed that the monthly hourly average of the ambient humidity during the central period of the day, during which the dryer will operate, does not have a significant variation. Therefore, it was decided to fix the 
values of this variable throughout the day, being $67 \%, 68 \%, 50 \%$ and $56 \%$ for the months of January, June, July and August respectively.

\subsubsection{Design Parameters of Solar Dryer}

To carry out the study of dryer performance, it is necessary to identify the different components that integrate the system. In Table 1 the main data of the arrangement are presented that are necessary for the modeling, which was previously defined based on a preliminary study.

The adopted dryer is a parallel flow tray type with capacity for two trolleys each with 15 trays separated by $6 \mathrm{~cm}$ with a total load of $80 \mathrm{~kg}$ of wet material. The physical dimensions were determined according to commercial models presented by Perry and Green (2008). To reduce energy consumption, the dryer has $85 \%$ air recirculation, a typical value for this type of dryer (Perry \& Green, 2008). The losses to the environment were set at $12 \%$ and $8 \%$ for the winter and summer months respectively (Costa, 2007). While the dryer is operating, it was considered a loss of $10 \%$ of the total energy that enters the solar collectors that represents the losses in pipes and reservoir (Duffie \& Beckman, 2013; Muller \& Heindl, 2006).

Table 1. Characteristics of the solar dryer

\begin{tabular}{lll}
\hline Description & Unit & Characteristic \\
\hline Type of manifold & & Vacuum tube \\
Collector area & $\mathrm{m}^{2}$ & 5 \\
Number of collectors & & 4 \\
Parallel Collectors & $\mathrm{L}$ & 2 \\
Reservoir volume & $\mathrm{mm}$ & 100 \\
Diameter of the Reservoir & $\mathrm{mm}$ & 520 \\
Reservoir length & & 980 \\
Material of reservoir insulation & $\mathrm{mm}$ & Polyurethane \\
Insulation thickness & & 50 \\
Type of drying chamber & & Parallel flow tray \\
Number of trolleys & & 2 \\
Tray per trolley & $\mathrm{mm}$ & 15 \\
Tray dimensions & $\mathrm{kg}$ & $1200 \times 800 \times 50$ \\
Nominal load & & 80 \\
\hline
\end{tabular}

\subsubsection{Dryer Operation Conditions}

Among the several species of medicinal plants known in Brazil, the main cultures whose timing and drying temperature were compatible for the use of solar drying were mapped in the literature, being these used as reference of the calculation basis of the dryer. Table 2 presents this survey.

Based on this survey, two operating times are considered, ts $=3 \mathrm{~h}$ and ts $=4 \mathrm{~h}$, with drying air temperature Ts $=$ $65{ }^{\circ} \mathrm{C}$. The initial moisture content considered is $75 \%$ b.u, the mean value of the data presented in the graph of Figure 3 and the final drying humidity considered and $10 \%$ b.u, the maximum final content allowed for commercialization of several medicinal plants 20 . The air velocity was pre-calculated in such a way that the energy balance and mass of the dryer allow to satisfy the estimated drying time, taking into account that the air has less than $90 \%$ relative humidity at the exit of the drying chamber to avoid condensation from water. The calculated velocities are $\mathrm{Var}=0.7 \mathrm{~m} / \mathrm{s}$ for ts $=4 \mathrm{~h}$ and $\mathrm{Var}=1.1 \mathrm{~m} / \mathrm{s}$ for ts $=3 \mathrm{~h}$, both within that used by several researchers (Table 2).

Aiming at the best possible use of the solar resource, the dryer will remain on at the highest radiation hours of each month. For January it will be from 1:00 p.m. to 5:00 p.m. for ts $=4: 00$ p.m. and from 1 p.m. to 4:00 p.m. for ts $=3: 00$ p.m. For the rest of the months the dryer will call from 12:00 $\mathrm{h}$ to 16:00 $\mathrm{h}$ for ts $=4 \mathrm{~h}$ and from 12:00 $\mathrm{h}$ to $15: 00 \mathrm{~h}$ for ts $=3 \mathrm{~h}$.

The drying kinetics considered is of constant drying rate since the period of constant drying rate predominates in materials with high initial moisture content (Rubio et al., 2018), as is the case of medicinal plants. In the graph of Figure 3, which was elaborated from the survey of several experimental studies, it is indicated that considering linear drying as constant is a good approximation for the purposes of this work. 
Table 2. Main operational parameters found in the literature for air forced convection drying

\begin{tabular}{llllll}
\hline Popular Name (Scientific) & $\mathbf{T s}\left[{ }^{\circ} \mathbf{C}\right]$ & $\mathbf{V}_{\mathrm{ar}}[\mathbf{m} / \mathbf{s}]$ & $\boldsymbol{\varphi}_{\mathrm{i}} / \boldsymbol{\varphi}_{\mathrm{f}}[\mathbf{b . s}]$ & $\mathbf{T s}[\mathbf{h}]$ & Reference \\
\hline Rosemary pepper (Lippia sidoides Cham.) & $60 / 70$ & 1 & $67 / 11$ & $1,4 / 0,8$ & (Radunz et al., 2002) \\
Marigold (Calendula officinalis L.) & $60 / 70$ & 0.5 & $88 / 10.3$ & $5.4 / 2.6$ & (Martins, 2005) \\
Lemongrass (Cymbopogon citratus (D.C.) Stapf) & 50 & $1.3 / 1.8$ & $76 / 9$ & $3.3 / 3.2$ & (Oliveira Prates et al., 2011) \\
Carqueja (Baccharis trimera) & 60 & 0.5 & & 2.58 & (Radunz et al., 2011) \\
Whale weed (Cordia verbenacera DC) & 60 & & $75 / 7$ & 2.58 & (Goneli, 2014) \\
Guaco (Mikania glomerata Sprengel) & 55 & 0.5 & $81.4 / 10$ & 4.08 & (Radunz et al., 2002) \\
Mint (Mentha $\times$ villosa Huds) & 50 & & & & (Radunz, 2004) \\
Moringa (Moringa oleifera Lam) & 60 & 1 & $69 / 9$ & 2.02 & (Carvalho, 2015) \\
Moro (Bauhinia cheilantha (Bong.) Steud.) & 60 & 1 & $79 / 8$ & 3.34 & (Alves Martins, 2015) \\
Thyeme (Thymus vulgaris L.) & $50 / 60$ & 2 & $75 / 9$ & $3.25 / 2.0$ & (Doymaz, 2011) \\
\hline
\end{tabular}

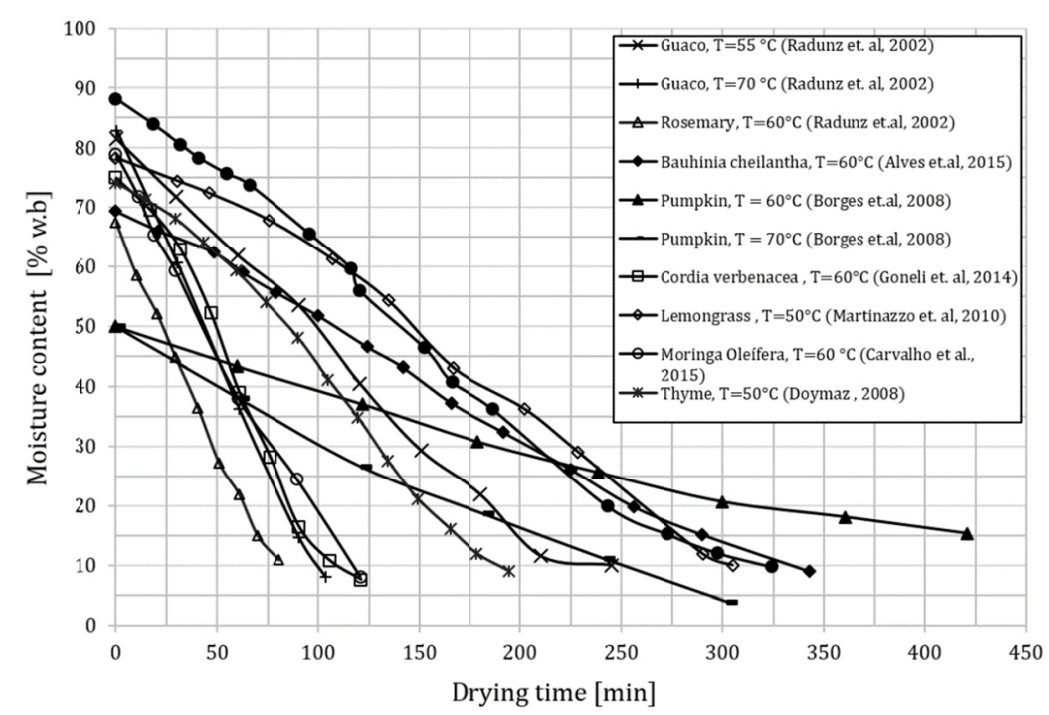

Figure 3. Drying of various medicinal plants

\section{Modelling of Solar Dryer}

The model developed in this work was based on energy balance equations, which is a practical approach and commonly used in works involving solar collectors (Rubio et al., 2018). Each component of the cycle is analyzed as a control volume, indicated by dashed lines in the scheme of Figure 4, applying energy and mass balance. Heat transfer analysis is also performed to calculate the thermal losses of the reservoir and the effectiveness of the heat exchanger. The Table 3 shows the list of abbreviations and acronyms used for the solar dryer design. 
Table 3. Abbreviations and acronyms used for solar dryer size

\begin{tabular}{ll}
\hline Parameter & Description \\
\hline$c p$ & Specific heat \\
$h$ & Enthalpy \\
$\mathrm{t}_{\mathrm{s}}$ & Drying time \\
$\mathrm{Z}_{\mathrm{int}}$ & Internal Length \\
$\mathrm{A}_{\mathrm{col}}$ & Collector Area \\
$\mathrm{A}_{\mathrm{s}}$ & Effective drying area \\
$\mathrm{F}_{\mathrm{rvl}}$ & Solar collector thermal losses \\
$\mathrm{F}_{\mathrm{r}(\tau \alpha)}$ & Optical Efficiency of Solar Collector \\
$\mathrm{C}_{\mathrm{q}}$ & Heat capacity rate of hot fluid \\
$\mathrm{C}_{\mathrm{f}}$ & Rate of heat capacity of cold fluid \\
$F S$ & Solar fraction \\
$G$ & Mass air flow in kg/h.m2 \\
$I$ & Solar irradiation on the collecting surface \\
$\mathrm{Q}_{\mathrm{max}}$ & Maximum possible rate of heat transfer \\
$\mathrm{Q}_{\mathrm{p}}$ & Thermal losses from the reservoir \\
$\mathrm{Q}_{\mathrm{solar}}$ & Rate of solar energy captured \\
$\mathrm{Q}_{\tau}$ & Actual heat exchange rate \\
$\mathrm{R}_{\mathrm{c}}$ & Drying rate \\
$\mathrm{T}_{\mathrm{amb}}$ & Local temperature \\
$\mathrm{T}_{\text {mod }}$ & Dimensional temperature \\
$\mathrm{T}_{\mathrm{res}}$ & Reservoir temperature \\
$\mathrm{T}_{\mathrm{s}}$ & Drying temperature \\
$\mathrm{T}_{\mathrm{wb}}$ & Wet bulb temperature \\
$\mathrm{V}_{\mathrm{ar}}$ & Drying air speed \\
$\Delta \mathrm{T}$ & Temperature variation \\
$\varphi_{\mathrm{i}}$ & Thermal efficiency of collectors \\
$\Phi_{\mathrm{f}}$ & Initial moisture content of the material \\
$\omega$ & Final moisture content of material \\
$\gamma_{\mathrm{ev}}$ & Absolute humidity \\
&
\end{tabular}

\subsection{Thermal Reservoir}

Under the following hypotheses: Uniform flow; Water as incompressible fluid; Water well mixed when the system is operating, then the water temperature is uniform with the position in the reservoir and varies only with time, $\mathrm{T}=\mathrm{T}(\mathrm{t})$ and with the relation between mass flow rates shown in Figure 4 energy rate is defined as:

$$
\dot{m}_{\text {res }} c p \frac{d T}{d t}=\dot{Q}_{P}+\dot{m}_{3} c p\left(T_{3}-T\right)+\dot{m}_{4} c p\left(T_{5}-T\right)
$$

Where, $\mathrm{T}$ represents the uniform temperature of the water at time $\mathrm{t}$. 


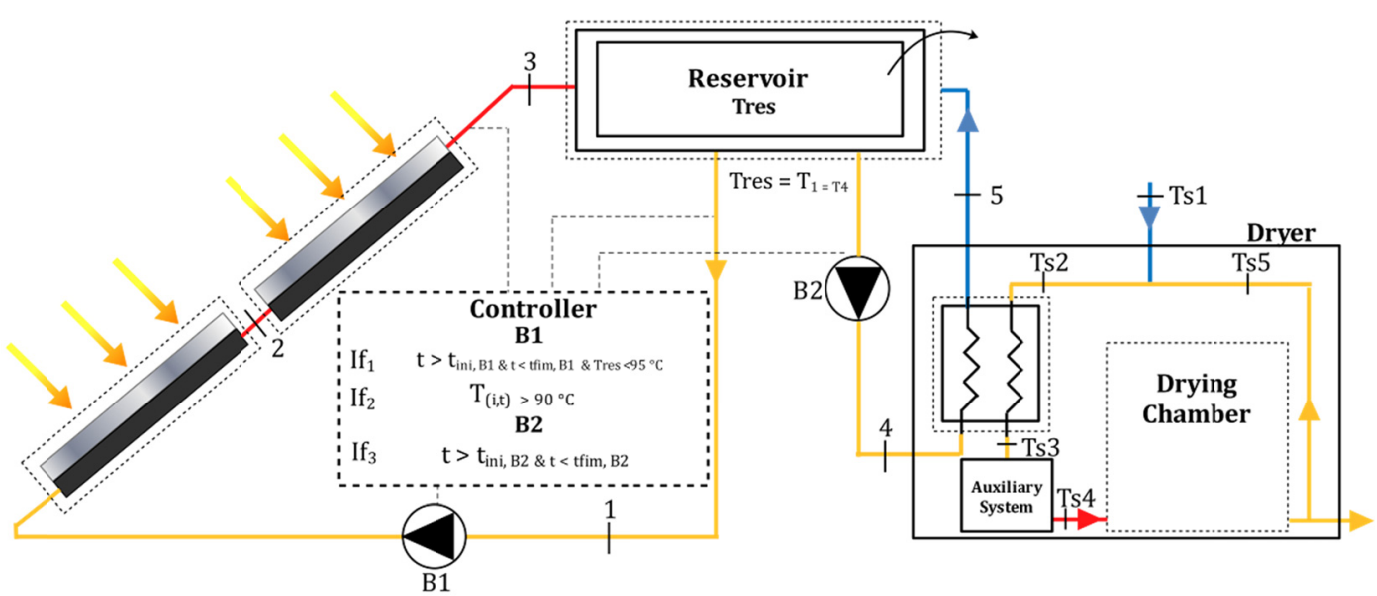

Figure 4. Demonstration of proposed solar dryer scheme

Since the states at the inputs and outputs are not constant over time, because the energy input of the system is solar radiation that varies during the day, an analytical solution is not feasible due to complex dependence between the terms (Duffie \& Beckman, 2013).

For engineering purposes, the numerical solution of Equation 1 via implicit Euler integration method produces satisfactory results (Duffie \& Beckman, 2013). Then, the solution of Equation 1 can be presented as in Equation 2.

$$
T_{\text {res }[i+1]}=T_{[I]}+\left[\dot{Q}_{P[i]}+\dot{m}_{3} c p\left(T_{3}-T_{\text {res }[i+1]}\right)+\dot{m}_{4} c p\left(T_{5}-T_{\text {res }[i+1]}\right)\right] \frac{\Delta t}{m_{r e s} c p}
$$

Where, $\Delta \mathrm{t}$ is the discrete time interval, being discretized in $5 \mathrm{~min}$, totaling 288 intervals per day.

\subsection{Losses in Reservoir While Dryer Does Not Operate}

The total thermal resistance of a reservoir is defined by the combination in series of the resistances to internal convection, conduction and the combination of convection and external radiation. The rate of transfer of heat from the fluid in the reservoir to the external medium occurs in the axial and radial directions. Therefore, the thermal insulation resistance of the reservoir $\left(R_{\text {iso }}\right)$ is determined by the combination of the axial $\left(R_{a}\right)$ and radial $\left(\mathrm{R}_{\mathrm{r}}\right)$ resistors in parallel (Bergman et al., 2014):

$$
R_{\text {iso }}=\frac{R_{r} R_{a}}{R_{r}+R_{a}}
$$

Since convection and radiation act in parallel on the surface of the thermal reservoir, the external resistance is defined by:

$$
R_{\text {ext,res }}=\frac{1}{\left(h_{\text {ext }, \text { res }}+h_{\text {rad }}\right) A_{\text {ext, res }}}
$$

The calculation of the external coefficient of the reservoir (hext, res) is done using the horizontal FC function of the EES. The external radiation coefficient is calculated by:

$$
h_{\text {rad }}=\varepsilon\left(T_{\text {ext }, \text { res }}+T_{a m b}\right)\left(T_{\text {ext }, \text { res }}^{2}+T_{a m b}^{2}\right)
$$

The last of the three resistors to be calculated is the internal resistance. For the calculation, we can use the correlation obtained by Savicki (2007) from a numerical simulation that describes the calculation of the internal resistance in cylindrical geometric thermal reservoir in the horizontal position:

$$
\begin{aligned}
R_{\text {int,res }}= & {\left[0.00261\left(R_{\text {iso }}+R_{\text {ext }}\right)+0.0081163\right] \cdot[-0.0048 \Delta T+1.1210] } \\
& \left\{0.079466 \cdot \tan \left[2.922037\left(T_{\text {mod }}-1 / 2\right)\right]+1 m 118018\right\} \cdot\left(0.25 / z_{\text {int }}\right) \cdot 0.4\left(z_{\text {int }} / r_{\text {int }, \text { res }}\right)
\end{aligned}
$$

Finally, the heat transfer rate is: 


$$
\dot{Q}_{P}=\frac{T_{r e s}-T_{a m b}}{R_{t o t}}
$$

Where, $R_{\text {tot }}$ is the sum of the three resistances mentioned above. For the calculations of combined convection and radiation thermal resistance, the surface temperature of the reservoir, which is not previously known, is required, falling into an iterative process that is solved by the EES.

As the internal temperature varies over time, new calculations of the internal and external resistance and the parameters that depend on these thermal resistances after the stipulated time increment $(\Delta \mathrm{t})$ become necessary.

\subsection{Solar Collector Sizing}

The useful power extracted from the solar collector and the primary input energy $\left(\mathrm{Q}_{\mathrm{col}}\right)$ of the system employed to increase the temperature of the working fluid circulating through the absorber and can be expressed as:

$$
\dot{Q}_{c o l}=\dot{m} c p\left(T_{\text {in }}-T_{\text {out }}\right)=\eta A_{c o l} I
$$

The efficiency of the collector can be obtained through a linear model, implemented and validated for different types of solar collectors, such as the flat plate collector (Ochoa \& Santos, 2016), which uses the following expression (Duffie \& Beckman, 2013):

$$
\eta=\operatorname{Fr}(\tau \alpha)-\operatorname{Fr} U L \frac{\left(T_{m}-T_{a m b}\right)}{I}
$$

Where, $T_{m}$ is the mean temperature of the fluid between the inlet and outlet of the manifold. The parameters Fr $(\tau \alpha)$ and FrUL are determined experimentally by assay. In Brazil, such values can be obtained from the tables presented by the National Institute of Metrology, Quality and Technology (INMETRO), in charge of establishing the guidelines and criteria to evaluate the performance of the collectors who, in turn, uses the standard ABNT NBR 15747-2 (ABNT, 2009) as a normative reference. For this study, the values adopted for Fr $(\tau \alpha)$ and FrUL are mean values recorded in the INMETRO table for vacuum solar collector.

Since the collector arrangement is a serial and parallel combination (Figure 5), the inlet temperature of the second battery collector is the outlet temperature of the first collector of the battery and it is assumed that the total inlet between the two batteries. The parallel-series arrangement allows a certain volume of water to reach a higher temperature due to the longer travel time inside the collectors, in addition to increasing the total flow of the collection system since the recommended flow rate is limited vacuum, on the order of 6-6.5 L/min (ABNT, 2009).

Considering that the total flow is distributed equally to each battery, all the collectors work with the same flow and exit temperature since the radiation is considered uniform. Therefore, the total energy entering the system is given by Equation 10 where $\mathrm{T} 3$ is calculated by Equation 9 .

$$
\dot{Q}_{\text {solar }}=\dot{m}_{3} c p\left(T_{3}-T_{1}\right)
$$

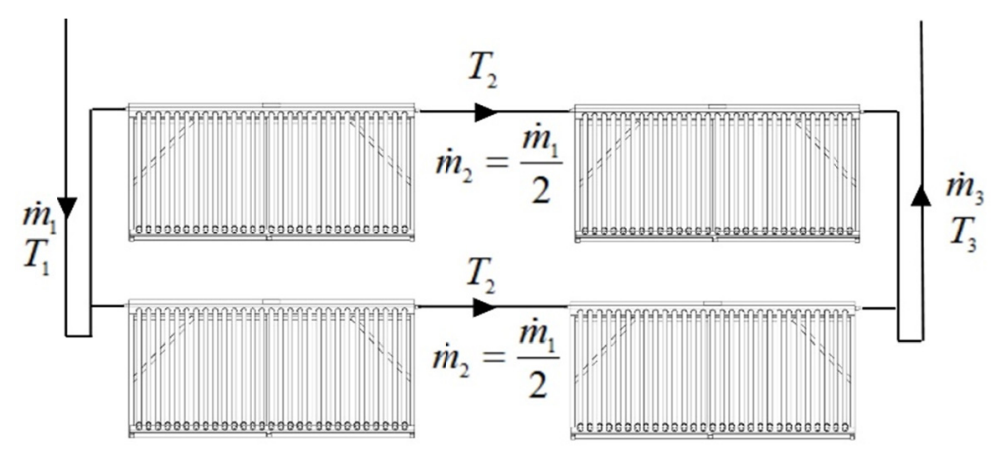

Figure 5. Arrangement of solar collectors

\subsection{Dimensioning of the Heat Exchanger}

The modeled exchanger is of the cross-flow finned type and both sides are unmixed. The physical characteristics are shown in Figure 6. 


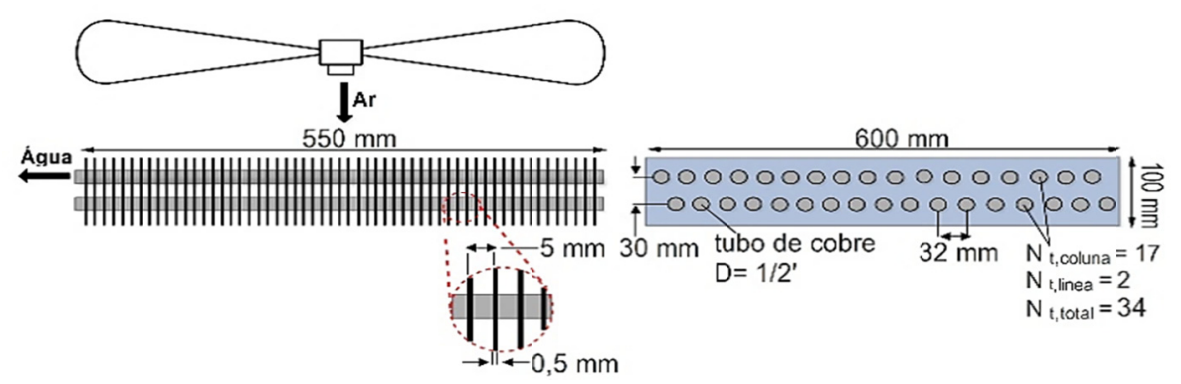

Figure 6. Characteristics of the heat exchanger

The procedure used for calculation and the effectiveness-NUT method, or $\varepsilon-N T U$ method. The effectiveness of the exchanger is defined as (Bergman et al., 2014):

$$
\varepsilon=\frac{\dot{Q}_{t}}{\dot{Q}_{\max }}
$$

Calculated the actual transfer rate, the exit temperature of the water and the air can be obtained by:

$$
\begin{aligned}
& T_{5}=T_{4}-\frac{\dot{Q}_{t}}{C_{q}} \\
& T_{s 3}=T_{s 2}-\frac{\dot{Q}_{t}}{C_{f}}
\end{aligned}
$$

For any heat exchanger, the effectiveness depends solely on the number of transfer units (NUT) and the relationship between Cmin and Cmax [33], allowing $\varepsilon$ to be obtained from these three parameters. The EES function is used to calculate the effectiveness of the type of exchanger in question. The NUT is a dimensionless parameter, being by Equation 14 (Bergman et al., 2014):

$$
N U T=\frac{U A}{C_{\min }}
$$

The UA product involves the overall heat transfer coefficient $(\mathrm{U})$, which is the inverse of the total resistance between water and air:

$$
U A=\frac{1}{R_{\text {int }}+R_{\text {con }, t}+R_{d}+R_{\text {out }, t}}
$$

Where, $R_{\text {int }}, t$ is the convective resistance between water and the inner surface of the tube, $R_{f}$ is the deposition resistance occurring on the inner surface of the tube, $R_{\text {cond }}, t$ is the resistance through conduction through the tube wall and $\mathrm{R}_{\text {out }} \mathrm{t}$ is the resistance between the air and the surface of the fins and the outer surface of the tube.

\subsection{Sizing of the Dryer}

For the dryer model the approach that studies the general behavior of the dryer is applied, applying the concepts of heat transfer and mass transfer. By this method it is possible to calculate the exit temperature and humidity of the drying chamber air, as well as the efficiency and estimated drying time (Bennamoun, 2011). In this line, the calculation method presented by COSTA (2007) is used for conventional hot air convective dryers. The method is based on the energy and mass balance, taking as input variables the quantity of material to be dried, initial humidity, desired final humidity, drying temperature and absolute humidity of the environment $(\omega \mathrm{S} 1)$. Then, applying energy and mass balance to the dryer (Figure 4):

$$
\begin{gathered}
\dot{m}_{S 1}+\dot{m}_{S 5}=\dot{m}_{S 3} \\
\dot{m}_{S 1} \omega_{S 1}+\dot{m}_{S 5} \omega_{S 5}=\dot{m}_{S 3} \omega_{S 3} \\
\dot{m}_{S 1} h_{S 1}+\dot{m}_{S 5} h_{S 5}=\dot{m}_{S 3} h_{S 3}
\end{gathered}
$$

The absolute humidity of the air at the exit of the drying chamber is:

$$
\omega_{S 5}=\omega_{S 3}+A_{S} R_{C} / \dot{m}_{S 3}
$$

For the constant rate period, the drying rate is defined by the following equation (Alzate, 2003): 


$$
R_{C}=h_{S}\left(T_{S 4}-T_{w b, S 4}\right) / \lambda_{e v}
$$

For the purpose of estimation, the convective coefficient of heat transfer for the case of air flow parallel to the drying surface (Daghihi \& Shafieian, 2016) can be calculated by:

$$
h_{S}=0.0204 G^{0.8}
$$

The power supplied by the auxiliary system to keep the constant inlet temperature in the dryer $\left(\mathrm{TS} 4=65^{\circ} \mathrm{C}\right)$ is:

$$
\dot{Q}_{\text {auc }}=\dot{m}_{S 3}\left(h_{S 4}-h_{S 2}\right)+\dot{Q}_{t}
$$

As a consequence of the above equation, the total power supplied to the dryer can be written as:

$$
\dot{Q}_{\text {TOTAL }}=\dot{Q}_{a u x}+\dot{Q}_{t}
$$

The solar fraction is defined as the ratio between the energy supplied by the solar heating system $\left(Q_{t}\right)$ and the energy demand of the dryer, mathematically:

$$
F S=\frac{\dot{Q}_{t}}{\dot{m}_{S 3}\left(h_{S 4}-h_{S 2}\right)}
$$

\subsection{Dimensioning the Controller}

For dimensionametno controller are defined three expressions logics IF to represent the dryer control system and determining, for example, when only is connected to pump 2, or when the unfavorable irradiation conditions or low water temperature in the reservoir, it is not convenient to switch on the dryer.

IF1: Links the pump 2 within a predefined time interval. This allows the pump 2 to function independently of the dryer, heating the water in the tank in the morning, before the start of the drying, and in the afternoon, after the drying has finished. Also, it limits the temperature of the water in the reservoir to $95{ }^{\circ} \mathrm{C}$ to avoid the boiling point.

IF2: This expression attempts to determine or predict a day with low radiation to the point that it does not compensate for turning on the dryer and thus avoid overuse of the auxiliary system. The condition used is based on the monitoring of the reservoir temperature at a given time of day before the start of drying. Then, if the temperature of the reservoir is less than $90{ }^{\circ} \mathrm{C} 15$ minutes before the start of the drying, it is understood that the radiation will remain low throughout the day. In this way, the program understands that only B1 will remain connected, water passing through the collectors, and B2 will remain off, even if it is the pre-programmed drying schedule.

IF3: Due to the high reservoir temperature and low irradiance conditions, the efficiency of the collectors can be very low or even to the point where the water is cooled rather than heated. So pump 2 will turn on, not only if it is within the scheduled time and water is below $95{ }^{\circ} \mathrm{C}$ (IF2), but if the efficiency of the collectors is greater than $5 \%$.

\section{Results and Discussion}

The Figure 7 shows the hourly mean of the water temperature in the reservoir for the four months and the two drying times evaluated. At dawn, the system only has the loss of energy by heat transfer to the environment, which depends not only on $\mathrm{T}_{\text {amb }}$ but also on $\mathrm{T}_{\text {res. }}$.

Therefore, as in January the temperature in the reservoir is higher, the fall is not accentuated in comparison to the other months. From 9:30 a.m., water begins to circulate through the collectors, increasing Tres up to $95{ }^{\circ} \mathrm{C}$, maximum setpoint temperature.

For the case of ts $=3 \mathrm{~h}$ (Figure 8 ), the temperature drop at the beginning of the drying is more pronounced as the increase in flow increases the energy demand required to heat the air and improves the heat transfer in the exchanger. 


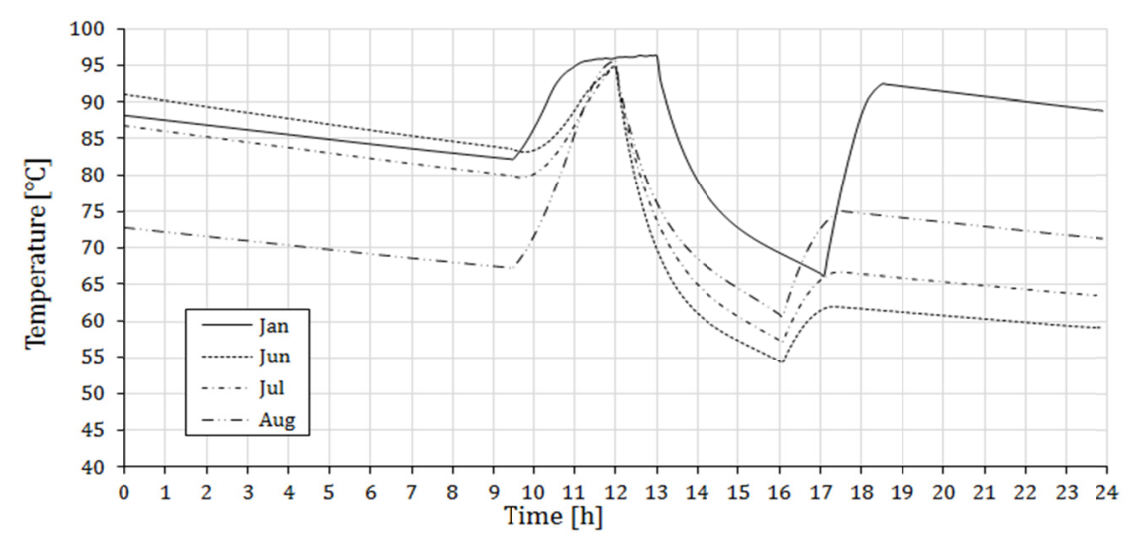

Figure 7. Average hourly monthly water temperature in the reservoir for ts $=4 \mathrm{~h}$

In Figures 9 and 10 is presented the sequence of three days with higher radiation of each month for drying of four hours. This graph allows us to observe particularities not present in the graph of the monthly hourly average (Figure 7). In January, July and August, the dryer can operate the three days. On the second day of June the dryer did not operate because it was considered a low radiation day (IF3). This allowed the tank temperature to be high at the beginning of the third day, allowing the dryer to operate. For the four months, FS decreases during drying due to radiation, and it is not possible to maintain a majority participation of the solar system in the total energy consumption of the drying.

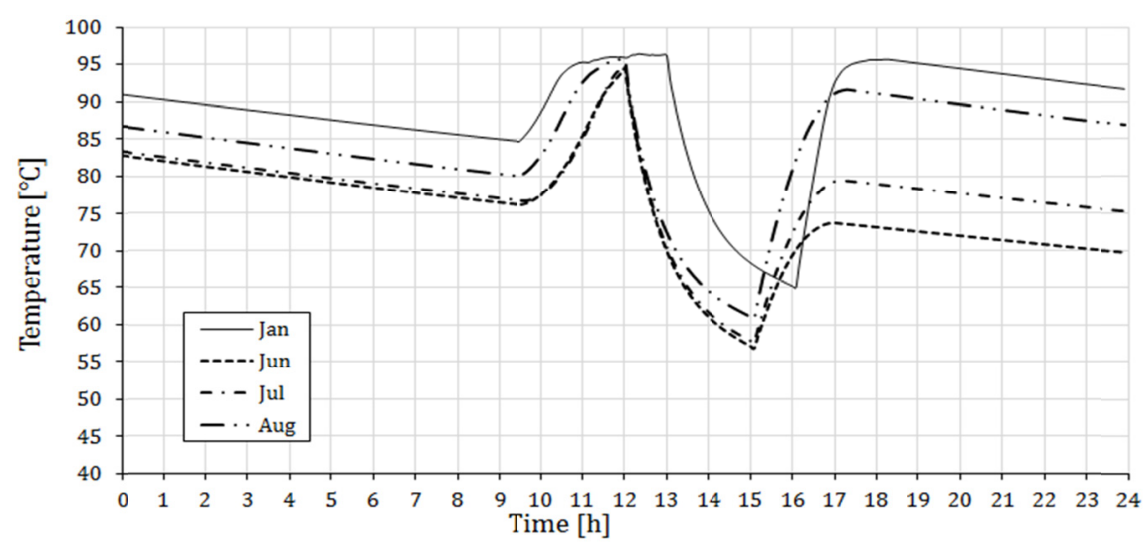

Figure 8. Average hourly monthly water temperature in the reservoir for ts $=3 \mathrm{~h}$

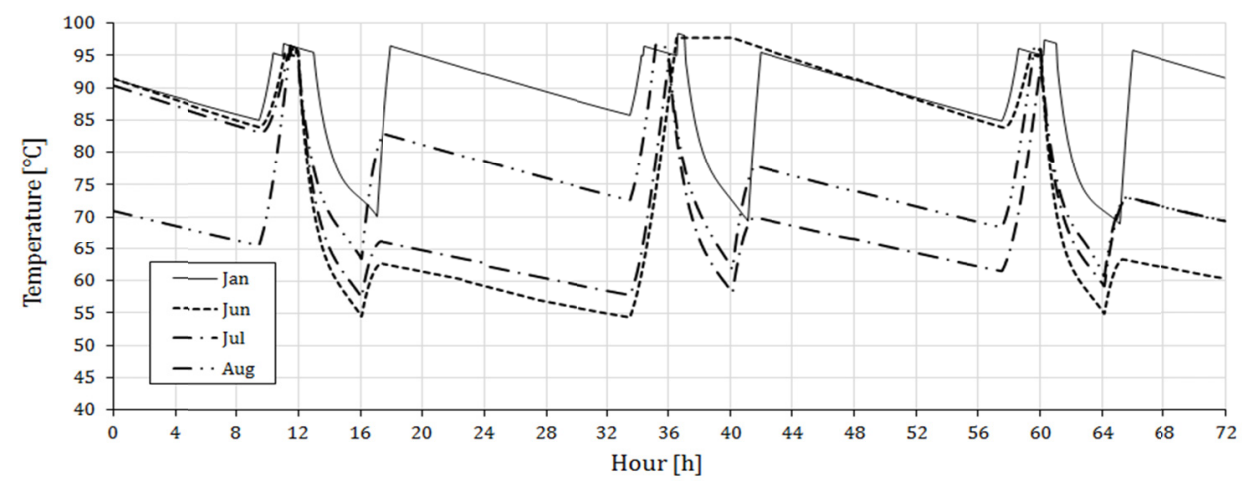

Figure 9. System behavior for the 3 days of highest radiation of each month for (ts $=4 \mathrm{~h}$ ) water temperature in the reservoir 


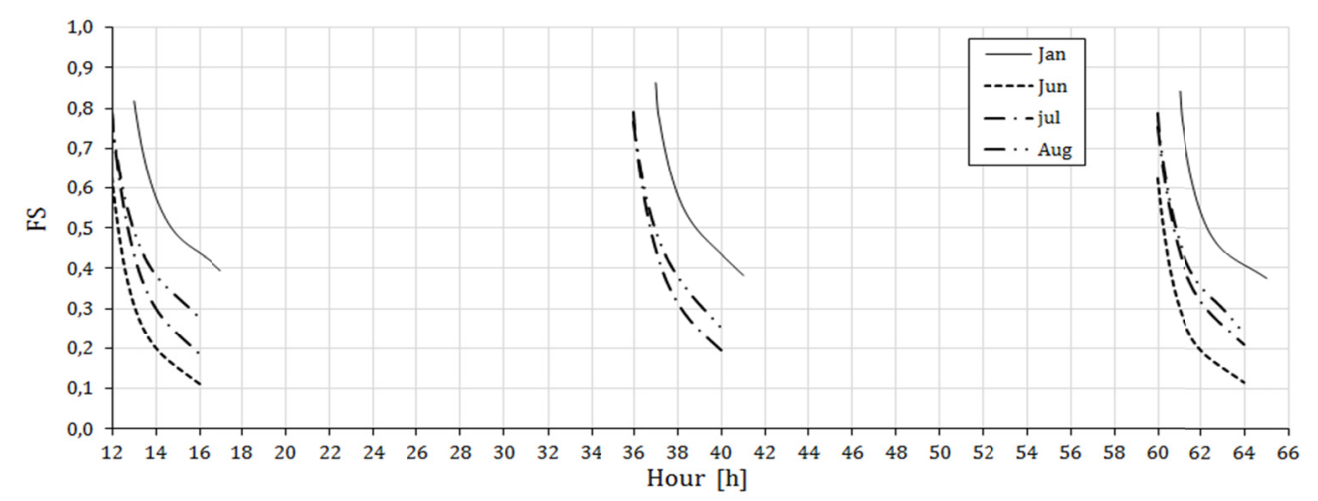

Figure 10. System behavior for the 3 days of highest radiation of each month for (ts $=4 \mathrm{~h}$ ) solar fraction

Tables 4 and 5 show the mean values and the respective standard deviation for each hour of drying, reservoir temperature, collector efficiency and energy balance for the solar dryer. As noted, the solar energy entering the system is less than the energy exchanged into the dryer air, as a result, the temperature in the reservoir decays throughout the drying. Since the heat transfer rate of the exchanger depends on the magnitude of the temperature difference between the two fluids, and due to the fact that $\mathrm{Q}_{\text {solar }}$ is less than $\mathrm{Q}_{t}$ the temperature in the reservoir drops, reducing the heat exchange capacity of the equipment. This increases the power supplied by the auxiliary system, which is required to maintain the fixed inlet temperature in the drying chamber.

As shown in Tables 4 and 5, the number of days estimated without operation decreases to the drying time of three hours, since it increases the time that the solar system is unloaded and with water passing through the collectors. Comparing the solar fraction for ts $=4 \mathrm{~h}$ and ts $=3 \mathrm{~h}$ it is observed that for ts $=3 \mathrm{~h}$ the FS and smaller, around $25 \%$ to $35 \%$. This is because reducing the drying time for the same load leads to the required power increase, and because $\mathrm{Q}_{\text {solar }}$ is the same since none of the characteristics of the energy pickup system has changed, the FS decreases. 
Table 4. Results for $\mathrm{Ts}=4 \mathrm{~h}$ and $\mathrm{Var}=0.7 \mathrm{~m} / \mathrm{s}$

\begin{tabular}{|c|c|c|c|c|c|}
\hline & & $t=1 h$ & $t=2 h$ & $\mathbf{t}=\mathbf{3 h}$ & $t=4 h$ \\
\hline \multicolumn{6}{|c|}{ January, days without operation $=0$} \\
\hline $\mathrm{T}_{\text {res }}$ & {$\left[{ }^{\circ} \mathrm{C}\right]$} & $86.6 \pm 5.0$ & $75.7 \pm 2.57$ & $71.0 \pm 2.4$ & $68.0 \pm 2.6$ \\
\hline$\eta$ & & $0.49 \pm 0.02$ & $0.53 \pm 0.01$ & $0.53 \pm 0.0$ & $0.52 \pm 0.0$ \\
\hline $\mathrm{Q}_{\mathrm{col}}$ & {$[\mathrm{W}]$} & $7332 \pm 1049$ & $7893 \pm 1054$ & $7409 \pm 110$ & $6791 \pm 122$ \\
\hline $\mathrm{Q}_{\mathrm{t}}$ & {$[\mathrm{W}]$} & $1379 \pm 1746$ & $9720 \pm 878$ & $8158 \pm 812$ & $7179 \pm 892$ \\
\hline $\mathrm{Q}_{\text {aux }}$ & {$[\mathrm{W}]$} & $6832 \pm 1742$ & $10580 \pm 876$ & $1182 \pm 816$ & $1328 \pm 901$ \\
\hline $\mathrm{Q}_{\text {TOTAL }}$ & [W] & $2063 \pm 1744$ & $20301 \pm 877$. & $1998 \pm 814$ & $2046 \pm 897$ \\
\hline FS & & $0.66 \pm 0.08$ & $0.48 \pm 0.04$ & $0.40 \pm 0.0$ & $0.35 \pm 0.0$ \\
\hline \multicolumn{6}{|c|}{ June, days without operation $=16$} \\
\hline $\mathrm{T}_{\text {res }}$ & {$\left[{ }^{\circ} \mathrm{C}\right]$} & $81.2 \pm 7.59$ & $65.2 \pm 2.84$ & $59.2 \pm 1.6$ & $56.1 \pm 1.3$ \\
\hline$\eta$ & & $0.37 \pm 0.04$ & $0.45 \pm 0.01$ & $0.47 \pm 0.0$ & $0.44 \pm 0.0$ \\
\hline $\mathrm{Q}_{\text {col }}$ & {$[\mathrm{W}]$} & $3306 \pm 706$ & $4213 \pm 565$ & $4097 \pm 575$ & $3221 \pm 579$ \\
\hline $\mathrm{Q}_{\mathrm{t}}$ & {$[\mathrm{W}]$} & $1452 \pm 3229$ & $7814 \pm 1154$ & $5426 \pm 641$ & $4189 \pm 544$ \\
\hline $\mathrm{Q}_{\mathrm{aux}}$ & [W] & $1879 \pm 3204$ & $2543 \pm 1143$ & $2782 \pm 651$ & $2918 \pm 583$ \\
\hline $\mathrm{Q}_{\text {TOTAL }}$ & {$[\mathrm{W}]$} & $3331 \pm 3216$ & $3325 \pm 1148$ & $3325 \pm 646$ & $3337 \pm 563$ \\
\hline FS & & $0.43 \pm 0.09$ & $0.23 \pm 0.03$ & $0.16 \pm 0.0$ & $0.12 \pm 0.0$ \\
\hline \multicolumn{6}{|c|}{ July, days without operation $=14$} \\
\hline $\mathrm{T}_{\text {res }}$ & {$\left[{ }^{\circ} \mathrm{C}\right]$} & $83.5 \pm 16.6$ & $69.2 \pm 2.89$ & $62.8 \pm 1.9$ & $59.1 \pm 1.7$ \\
\hline$\eta$ & & $0.37 \pm 0.04$ & $0.44 \pm 0.02$ & $0.45 \pm 0.0$ & $0.44 \pm 0.0$ \\
\hline $\mathrm{Q}_{\mathrm{col}}$ & {$[\mathrm{W}]$} & $3496 \pm 834$ & $4199 \pm 701$ & $4096 \pm 635$ & $3337 \pm 598$ \\
\hline $\mathrm{Q}_{\mathrm{t}}$ & [W] & $1274 \pm 2179$ & $7817 \pm 977$ & $5692 \pm 653$ & $4484 \pm 575$ \\
\hline $\mathrm{Q}_{\text {aux }}$ & {$[\mathrm{W}]$} & $8823 \pm 2165$ & $1372 \pm 975$. & $1585 \pm 659$ & $1713 \pm 590$ \\
\hline $\mathrm{Q}_{\text {TOtAL }}$ & {$[\mathrm{W}]$} & $2156 \pm 2172$ & $2153 \pm 976$ & $2155 \pm 656$ & $2161 \pm 582$ \\
\hline FS & & $0.59 \pm 0.10$ & $0.36 \pm 0.04$ & $0.26 \pm 0.0$ & $0.20 \pm 0,0$ \\
\hline \multicolumn{6}{|c|}{ August, days without operation $=2$} \\
\hline $\mathrm{T}_{\text {res }}$ & {$\left[{ }^{\circ} \mathrm{C}\right]$} & $84.8 \pm 5.77$ & $72.0 \pm 2.59$ & $66.3 \pm 1.8$ & $62.7 \pm 1.9$ \\
\hline$\eta$ & & $0.43 \pm 0.03$ & $0.48 \pm 0.01$ & $0.49 \pm 0.0$ & $0.46 \pm 0.0$ \\
\hline $\mathrm{Q}_{\mathrm{col}}$ & [W] & $5015 \pm 786$ & $5789 \pm 667$ & $5576 \pm 763$ & $4504 \pm 821$ \\
\hline $\mathrm{Q}_{\mathrm{t}}$ & [W] & $1318 \pm 2008$ & $8758 \pm 879$ & $6863 \pm 633$ & $5651 \pm 648$ \\
\hline $\mathrm{Q}_{\mathrm{aux}}$ & [W] & $8375 \pm 1994$ & $1278 \pm 877$ & $1468 \pm 639$ & $1596 \pm 663$ \\
\hline $\mathrm{Q}_{\text {total }}$ & [W] & $2156 \pm 2001$ & $2153 \pm 878$ & $2155 \pm 636$ & $2161 \pm 656$ \\
\hline FS & & $0.61 \pm 0.09$ & $0.40 \pm 0.04$ & $0.31 \pm 0.0$ & $0.26 \pm 0.0$ \\
\hline
\end{tabular}


Table 5. Results for $\mathrm{Ts}=3 \mathrm{~h}$ and $\mathrm{Var}=1.1 \mathrm{~m} / \mathrm{s}$

\begin{tabular}{|c|c|c|c|c|}
\hline & & $\mathbf{t}=\mathbf{1 h}$ & $t=2 h$ & $\mathbf{t}=\mathbf{3 h}$ \\
\hline \multicolumn{5}{|c|}{ January, days without operation $=0$} \\
\hline $\mathrm{T}_{\mathrm{res}}$ & {$\left[{ }^{\circ} \mathrm{C}\right]$} & $84.5 \pm 6.2$ & $71.5 \pm 2.6$ & $66.7 \pm 2.1$ \\
\hline$\eta$ & & $0.50 \pm 0.02$ & $0.54 \pm 0.01$ & $0.54 \pm 0.00$ \\
\hline $\mathrm{Q}_{\mathrm{col}}$ & {$[\mathrm{W}]$} & $7287 \pm 1126$ & $7995 \pm 1031$ & $7802 \pm 1093$ \\
\hline $\mathrm{Q}_{\mathrm{t}}$ & {$[\mathrm{W}]$} & $15888 \pm 2661$ & $10406 \pm 1095$ & $8446 . \pm 878$ \\
\hline$Q_{\text {aux }}$ & {$[\mathrm{W}]$} & $15969 \pm 2654$ & $21426 \pm 1091$ & $23401 \pm 885$. \\
\hline $\mathrm{Q}_{\text {TOTAL }}$ & {$[\mathrm{W}]$} & $31857 \pm 2657$ & $31833 \pm 1093$ & $31848 \pm 881$. \\
\hline FS & & $0.49 \pm 0.08$ & $0.32 \pm 0.03$ & $0.26 \pm 0.02$ \\
\hline \multicolumn{5}{|c|}{ June, days without operation $=15$} \\
\hline $\mathrm{T}_{\text {res }}$ & {$\left[{ }^{\circ} \mathrm{C}\right]$} & $80.8 \pm 7.3$ & $65.1 \pm 2.8$ & $59.1 \pm 1.6$ \\
\hline$\eta$ & & $0.37 \pm 0.04$ & $0.44 \pm 0.03$ & $0.45 \pm 0.04$ \\
\hline$Q_{\text {col }}$ & {$[\mathrm{W}]$} & $3474 \pm 730$ & $4197 \pm 611$ & $3974 \pm 667$ \\
\hline $\mathrm{Q}_{\mathrm{t}}$ & {$[\mathrm{W}]$} & $14333 \pm 3137$ & $7772 \pm 1148$ & $5369 \pm 666$ \\
\hline$Q_{\text {aux }}$ & {$[\mathrm{W}]$} & $18978 \pm 3112$ & $25473 \pm 1137$ & $27876 \pm 676$ \\
\hline $\mathrm{Q}_{\text {TOTAL }}$ & {$[\mathrm{W}]$} & $33311 \pm 3125$ & $33246 \pm 1142$ & $33246 \pm 671$ \\
\hline FS & & $0.44 \pm 0.09$ & $0.25 \pm 0.10$ & $0.19 \pm 0,11$ \\
\hline \multicolumn{5}{|c|}{ July, days without operation $=11$} \\
\hline $\mathrm{T}_{\text {res }}$ & {$\left[{ }^{\circ} \mathrm{C}\right]$} & $81.3 \pm 7.31$ & $65.6 \pm 2.7$ & $59.7 \pm 1.5$ \\
\hline$\eta$ & & $0.39 \pm 0.04$ & $0.46 \pm 0.01$ & $0.47 \pm 0.01$ \\
\hline $\mathrm{Q}_{\mathrm{col}}$ & {$[\mathrm{W}]$} & $3733 \pm 766$ & $4480 \pm 576$ & $4321 \pm 536$ \\
\hline $\mathrm{Q}_{\mathrm{t}}$ & {$[\mathrm{W}]$} & $14531 \pm 3113$ & $8000 \pm 1129$ & $5622 \pm 625$ \\
\hline$Q_{\text {aux }}$ & {$[\mathrm{W}]$} & $18749 \pm 3091$ & $25237 \pm 1125$ & $27629 \pm 635$ \\
\hline $\mathrm{Q}_{\text {TOTAL }}$ & {$[\mathrm{W}]$} & $33281 \pm 3102$ & $33238 \pm 1127$ & $33252 \pm 630$ \\
\hline FS & & $0.43 \pm 0.09$ & $0.24 \pm 0.03$ & $0.16 \pm 0.01$ \\
\hline \multicolumn{5}{|c|}{ August, days without operation $=1$} \\
\hline $\mathrm{T}_{\text {res }}$ & {$\left[{ }^{\circ} \mathrm{C}\right]$} & $82.5 \pm 6.9$ & $68.0 \pm 2.6$ & $62.7 \pm 1.7$ \\
\hline$\eta$ & & $0.44 \pm 0.03$ & $0.50 \pm 0.01$ & $0.51 \pm 0.01$ \\
\hline $\mathrm{Q}_{\mathrm{col}}$ & {$[\mathrm{W}]$} & $5108 \pm 925$ & $6020 \pm 721$ & $5847 \pm 720$ \\
\hline $\mathrm{Q}_{\mathrm{t}}$ & {$[\mathrm{W}]$} & $15037 \pm 2954$ & $8973 \pm 1075$ & $6836 \pm 693$ \\
\hline$Q_{\text {aux }}$ & {$[\mathrm{W}]$} & $17648 \pm 2977$ & $23665 \pm 1227$ & $25805 \pm 950$ \\
\hline $\mathrm{Q}_{\text {TOTAL }}$ & {$[\mathrm{W}]$} & $32685 \pm 2965$ & $32638 \pm 1151$ & $32642 \pm 821$ \\
\hline FS & & $0.46 \pm 0.09$ & $0.27 \pm 0.03$ & $0.20 \pm 0.02$ \\
\hline
\end{tabular}

The average energy consumption per kilogram of evaporated water was $6220 \mathrm{~kJ} / \mathrm{kg}$, a value close to that described by Melo et al. (2002) which shows an average consumption of $7256 \mathrm{~kJ} / \mathrm{kg}$ of water removed for the guaco using $55^{\circ} \mathrm{C}$ air temperature and upflow LPG drier.

Under the loading condition, the arrangement in question can not keep the FS high during the entire drying, and the auxiliary heat source must be increased at the end of drying. This is reflected in the rapid fall of the FS shown by Figure 10.

In order to show the versatility of the proposal and the model as an optimization tool, we present the result of the comparison between the arrangement of 4 collectors and the $100 \mathrm{~L}$ reservoir already analyzed, $\mathrm{N}_{\text {col }}=4$ and $\mathrm{V}_{\text {res }}=$ $100 \mathrm{~L}$, and an arrangement of 8 collectors $\mathrm{N}_{\text {col }}=8$ and volume of reservoir of $400 \mathrm{~L}, \mathrm{~N}_{\text {col }}=8$ and $\mathrm{V}_{\text {res }}=400 \mathrm{~L}$.

In Figures 11 and 12 it is observed that with $\mathrm{Ncol}=8$ the lower temperature variation is presented in the tank and consequent greater participation of solar energy in the total energy consumption. Even so, FS is less than one, due to the limited temperature gradient between water and the air outlet temperature, requiring the auxiliary source to reach $65^{\circ} \mathrm{C}$. 


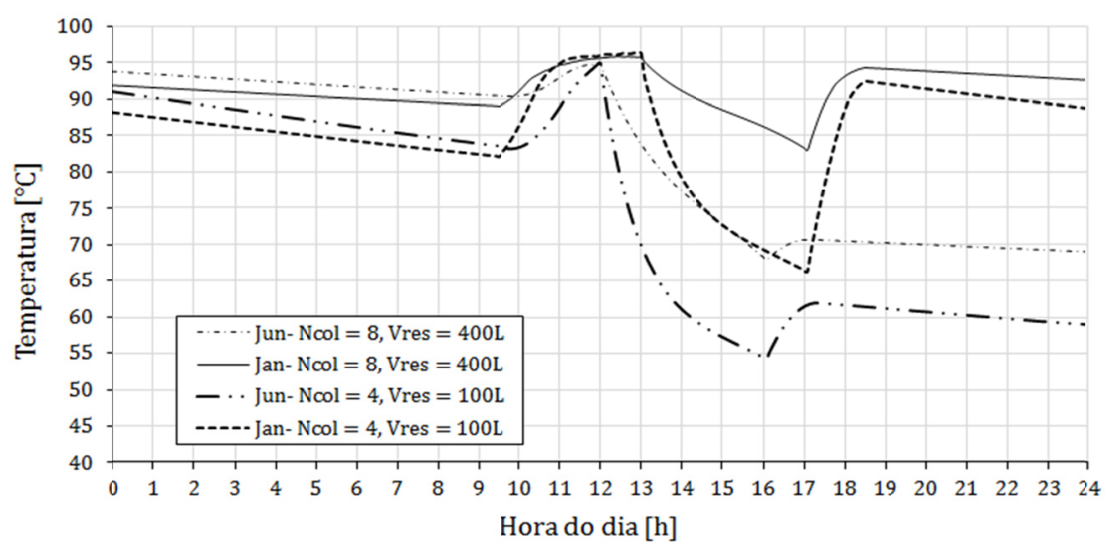

Figure 11. Comparison of performance between $\mathrm{N}_{\text {col }}=4$ and $\mathrm{V}_{\text {res }}=100 \mathrm{~L}$ and $\mathrm{N}_{\text {col }}=8$ and Vres $=400 \mathrm{~L}$ for (Ts $=4 \mathrm{~h}$ ) water temperature in the reservoir

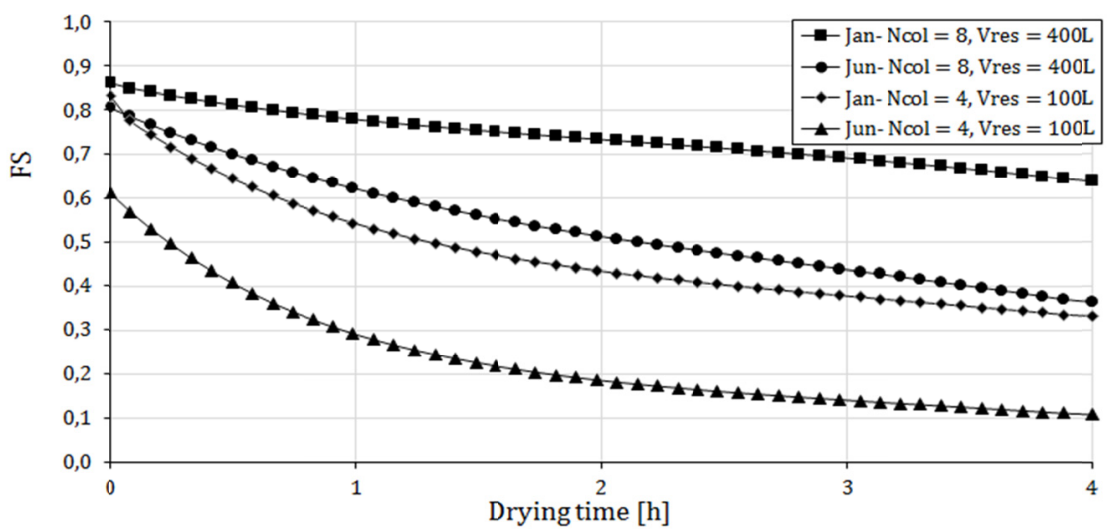

Figure 12. Comparison of performance between $\mathrm{N}_{\mathrm{col}}=4$ and $\mathrm{V}_{\text {res }}=100 \mathrm{~L}$ and $\mathrm{N}_{\mathrm{col}}=8$ and Vres $=400 \mathrm{~L}$ for (Ts $=4 \mathrm{~h})$ solar fraction

Due to the FS values reached, the proposed system is promising when comparing the results with other dryers found in the literature.

Boughali et al. (2009) evaluates an indirect solar-electric hybrid dryer without thermal storage, with a collector area of $2.45 \mathrm{~m}^{2}$ and an electric resistance of $3.75 \mathrm{~kW}$ located at the exit of the solar capture zone. The capacity of the dryer is $12 \mathrm{~kg}$ of fresh sample. The experiment, with a maximum radiation of up to $800 \mathrm{~W} / \mathrm{m}^{2}$, presents drying air velocity of $1 \mathrm{~m} / \mathrm{s}$ and $2 \mathrm{~m} / \mathrm{s}$ FS decreased from $25.07 \%$ to $13.22 \%$, while the participation of the auxiliary heater increased from $74.92 \%$ to $86.78 \%$. The values of solar FS obtained by Boughali et al. (2009), the results presented in Tables IV and V are lower, in which, even in June with a mean maximum radiation of $460 \mathrm{~W} / \mathrm{m}^{2}$, FS remained between $44 \%$ and $13 \%$ during drying. This highlights the important energy input of the storage system into total energy consumption.

Daghigh and Shafieian (2016) performed an experimental evaluation of a similar solar dryer with the difference that the auxiliary heating system is located in the reservoir and not the heat exchanger output. The solar capture was carried out by a vacuum solar collector with absorption area of $2.06 \mathrm{~m}^{2}$ and storage capacity of the reservoir was $130 \mathrm{~L}$, with electrical resistance of $2 \mathrm{~kW}$. The tests were done without load on the dryer, ie empty.

The results of Daghigh and Shafieian (2016) indicated that the maximum collector outlet temperature was around $71{ }^{\circ} \mathrm{C}$ and the maximum observed outlet temperature of the air in the heat exchanger during the experiment was approximately $44^{\circ} \mathrm{C}$. The relationship between collector absorption area and storage volume is very small, compared to the values presented in Table 1, so the temperatures reached are lower than those calculated in the present work.

As seen in Figures 7 and 8, the temperature in the reservoir can reach $95{ }^{\circ} \mathrm{C}$ reaching $65^{\circ} \mathrm{C}$ on the end of the drying period. By the location of the auxiliary system, the Daghigh and Shafieian (2016) proposal does not allow 
to control the exit temperature of the drying air and therefore also does not allow to control the drying time being a great operational disadvantage.

\section{Conclusions}

The proposed dryer presented a satisfactory performance and superior when compared to the results found in the bibliography and recent research. The temperature of the affected water allows to maintain a favorable temperature differential with the drying air in the heat exchanger, which benefits the thermal exchange and elevates FS. The temperature at $65{ }^{\circ} \mathrm{C}$ avoids prolonging the drying process for more than a day of sunshine, as is often the case in indirect solar dryers without energy storage and without an auxiliary system.

In the current operating condition, due to the temperature gradient between drying air and water, it is not possible to obtain a $100 \%$ solar share, even with the use of a large number of collectors. Even so, solar FS is high which translates into a reduction in operating cost between 20 and $47 \%$ when compared to conventional systems.

It is worth noting that the proposed model can aid in the development and optimization of solar drying systems, making possible the analysis of the effect caused by the customization or adequacy of the project, whether due to climatic conditions or structural changes.

As a continuation of this research, we intend to prepare the experimental model of the system for convalidating the numerical results presented in the article.

\section{Acknowledgements}

The authors would like to acknowledge financial support by Federal University of Latin American Integration (UNILA).

\section{References}

Agrawal, A., \& Sarviya, R. (2016). A review of research and development work on solar dryers with heat storage. International Journal of Sustainable Energy, 35(6), 583-605. https://doi.org/10.1080/14786451. 2014.930464

Alves Martins, J. J., Cordeiro de Sousa, F., Trindade Rocha, A. P., Nobre Martins, J., \& Palmeira Gomes, J. (2015). Estudo da cinética de secagem de folhas de Bauhinia cheilantha (Bong.) Steud. (Mororó). Revista Cubana de Plantas Medicinales, 20(4), 397-408.

Alzate, C. E. O. (2003). Procesamiento de Alimentos. Universidad Nacional de Colombia.

Bal, L. M., Satya, S., \& Naik, S. (2010). Solar dryer with thermal energy storage systems for drying agricultural food products: A review. Renewable and Sustainable Energy Reviews, 14, 2298-2314. https://doi.org/ 10.1016/j.rser.2010.04.014

Bennamoun, L. (2011). An overview on application of exergy and energy for determination of solar drying efficiency. Renewable and Sustainable Energy Reviews, 15(7), 3371-3379. https://doi.org/10.1016/ j.rser.2011.04.027

Bennamoun, L. (2013). Improving solar dryer's performances using design and thermal heat storage. Food Engineering, 2(5), 230-248. https://doi.org/10.1007/s12393-013-9073-4

Bergman, T. L., Lavine, A. S., Incropera, F. P., \& Dewitt, D. P. (2014). Fundamentos de Transferência de Calor e de Massa (7th ed.). LTC.

Boughali, S., Benmoussa, H., Bouchekima, B., Mennouche, D., Bouguettaia, H., \& Bechki, D. (2009). Crop Drying by Indirect Active Hybrid Solar-Electrical Dryer in the Eastern Algerian Septentrional Sahara. Solar Energy, 83, 2223-223. https://doi.org/10.1016/j.solener.2009.09.006

Branquinho, N., Silva, F., Resende, O., Barbosa, L. C., Oliveira, D., \& Pedroso, R. (2018). Influence of Drying in Hyptis pectinata Essential Oil. Journal of Agricultural Scince, 10(4), 96-103. https://doi.org/10.5539/ jas.v10n4p96

Carvalho, Y., Silva, B., Souza, M., Andeade, L., \& Silva, G. (2015). Cinética de secagem das folhas de Moringa oleifera Lam. Blucher Chemical Engineering Proceedings, 2(1), 1739-1747. https://doi.org/10.5151/ ENEMP2015-SE-635

Castro Melo, E., Radunz, L. L., \& de Alvarenga, R. C. (2004). Influencia do processo de secagem na qualidade de plantas medicinais. Engenharia na Agricultura, 12(4), 307-315.

Costa, E. C. (2007). Secagem Industrial. Blucher, São Pablo. 
Daghigi, R., \& Shafieian, A. (2016). Na experimental study of a heat pipe evacated tube solar dryer with heat recovery system. Renewable Energy, 96, 872-880. https://doi.org/10.1016/j.renene.2016.05.025

Doymaz, I. (2011). Drying of thyme (Thymus vulgaris L.) and selection of a suitable thin-layer drying model. Journal of Food Processing and Preservation, 35(4), 458-465. https://doi.org/10.1111/j.1745-4549.2010. 00488.x

Duffie, J. A., \& Beckman, W. A. (2013). Solar Engineering of Thermal Processes (4th ed.). John Wiley e Sons, Inc, New Jersey. https://doi.org/10.1002/9781118671603

FAO. (2016). Energy, agriculture and climate change. Retrieved from http://www.fao.org/3/a-i6382e.pdf

Feng, H., Yin, Y., \& Tang, J. (2012). Microwave drying of food and agricultural materials: basics heat and mass transfer modeling. Food Engineering Reviews, 4(2), 89-106. https://doi.org/10.1007/s12393-012-9048-X

Fudholi, A., Sopian, K., Gabbasa, M., Bakhtyar, B., Yahya, M., Ruslan, M. H., \& Ma, S. (2015). Techno-economic of solar drying systems with water based solar collectors in Malaysia: A review. Renewable and Sustainable Energy Reviews, 51, 809-820. https://doi.org/10.1016/j.rser.2015.06.059

Goneli, A., Nasu, A., Gancedo, R., Araujo, W., \& Sarath, K. (2014). Cinética de secagem de folhas de erva baleeira (Cordia verbenacea DC.). Revista Brasileira de Plantas Medicinais, 16(2, Supl. 1), 434-443. https://doi.org/10.1590/1983-084X/13_041

Hii, C., Jangam, A., Ong, S., \& Mujumdar, A. (2012), Solar Drying: Fundamentals, Applications and Innovations. Elsevier.

Ivanov, T. C. (2017). Caracterização da qualidade de energia elétrica no setor rural do estado do Paraná (Escola de Engenharia da Universidade Tecnológica Federral do Paraná, Pato Branco).

Lorenzi, H., \& Matos, F. (2008). Plantas medicinais no Brasil: Nativas e exóticas. Plantarum.

Martins, P. M. (2005). Influencia de parâmetros de secagem e armazenamento sobre principios ativos de interesse de duas espécies medicinais: Guaco (Mikania glomerata Spreng.) e Calêndula (Calendula officinalis L.) (Tese, Doutorado em Producao Vegetal, Universidade Estadual do Norte Fluminense).

Melo, E. d. C., Randuz, L. L., \& Berbert, P. A. (2002). Secador a gas para plantas' medicinais e aromáticas. 4th Encontro de Energia no Meio Rural.

Mujumdar, A. S. (2014). Handbook of industrial drying (4th ed.). CRC Press. https://doi.org/10.1201/b17208

Muller, J., \& Heindl, A. (2006). Drying of medicinal plants. Springer. https://doi.org/10.1007/1-4020-5449-1_17

Nems, M., Nems, A., \& Pacyga, P. (2018). A Granite Bed Storage for a Small Solar Dryer. Materials, 11. https://doi.org/10.3390/ma11101969

Ochoa, N., \& Santos, M. (2016). Modeling and Simulation of a Solar-Thermal System for its Efficient Implementation in Quito (Ecuador). IEEE Latin America Transactions, 14(5), 2271-2279. https://doi.org/ 10.1109/TLA.2016.7530423

Oliveira Prates, M. De, Assunção Pizziolo, T. De, Castro Melo, E. de Rocha, R. P., \& Nicacio, V. N. (2011). Controle da temperatura e velocidade do ar de secagem em um secado de plantas medicinais. Engenharia na Agricultura, 18(2), 101-111. https://doi.org/10.13083/1414-3984.v19n02a01

Perry, R., \& Green, D. (2008). Perry's Chemical Engineer's Handbook (8th ed.). McGraw-Hill.

Pimentel, F. A. (2008). Influencia da temperatura de secagem sobre o rendimento e a composição química do óleo essencial de tanaecium nocturnum. Química Nova, 31(3), 523-526. https://doi.org/10.1590/ S0100-40422008000300011

Prakash, O., \& Kumer, A. (2013). Historical review and recent trends in solar drying systems. International Journal of Green Energy, 10, 690-738. https://doi.org/10.3390/ma11101969

Radunz, L. L., Amaral, A. D., Mossi, A. J., Melo, E. D. C., \& Rocha, R. P. (2011). Avaliação da cinética de secagem de carqueja. Engenharia na Agricultura, 19(1), 19-27. https://doi.org/10.13083/reveng.v19i1.147

Radunz, L. L., Melo, E. C., Martinz, P. M., Santos, R. H., Santos, R. R., \& Machado, M. C. (2002). Secagem de alecrim pimenta (Lippia sidoides Cham.) em secador de leito fixo. Revista Brasileira de Plantas Medicinais, 5(1), 79-82.

Radunz, L. L., Melo, E. C., Roha, R. P., \& Santos, R. H. (2002). Secagem de guaco (Mikania glomerata Sprengel) em secador de bandejas. XXXI Congresso Brasileiro de Engenharia Agrícola, Salvador. 
Randuz, L. L. (2004). Efeito da temperatura do ar de secagem no teor e na composição dos Óleos essências de guaco (Mikania glomerata Sprengel) e hortelã-comum (Mentha x villosa Huds) (Tese, Doutorado em Engenharia Agrícola, Universidade Federal de Viçosa).

Rubio, L. M., Brito Filho, J. P., \& Henríquez, J. R. (2018). Performance of a PV/T Solar Collector in a Tropical Monsoon Climate City in Brazil. IEEE Latin America Transactions, 16(1), 140-147. https://doi.org/ 10.1109/TLA.2018.8291466

Savicki, D. (2007). Analise tridimensional e investigação do comportamento térmico e hidrodinâmico de reservatórios cilíndricos térmicos (Doutorado em Engenharia Mecânica, Escola de Engenharia da Universidade do Rio Grande do Sul, Porto Alegre).

Tripathi, H., Suresh, R., Kumar, S., \& Khan, F. (2017). International trade in medicinal and aromatics plants: A case study of past 18 years. Journal of Medicinal and Aromatic Plant Sciences, 39(1).

Vasisht, K., Sharma, N., \& Karan, M. (2016). Current Perspective in the International Trade of Medicinal Plants Material: An Update. Current Pharmaceutical Design, 22(27), 4288-336. https://doi.org/10.2174/1381612 822666160607070736

\section{Copyrights}

Copyright for this article is retained by the author(s), with first publication rights granted to the journal.

This is an open-access article distributed under the terms and conditions of the Creative Commons Attribution license (http://creativecommons.org/licenses/by/4.0/). 